\title{
Metallurgical and Mechanical Behaviors of 309L-Si and ERNiCrMo-3 Dissimilar Weld on ASTM A182 F22 Steel
}

\author{
Douglas Neves Garcia ${ }^{a^{*}}$ (D), Valtair Antônio Ferraresi ${ }^{b}$, Carlos Alberto Mendes da Mota ${ }^{c}$ \\ ${ }^{a}$ Universidade Federal do Pará (UFPA), Faculdade de Engenharia Mecânica (FEM), 68464-000, \\ Tucurui, PA, Brasil. \\ ${ }^{b}$ Universidade Federal de Uberlândia (UFU), Laprosolda - Centro para Pesquisa e Desenvolvimento de \\ Processos de Soldagem, 38408-100, Uberlândia, MG, Brasil. \\ 'Universidade Federal do Pará (UFPA), Programa de Pós-Graduação em Engenharia Mecânica, \\ Getsolda - Grupo de Estudos em Tecnologia da Soldagem, 66075-110, Belém, PA, Brasil.
}

Received: December 17, 2019; Revised: April 07, 2020; Accepted: May 09, 2020

\begin{abstract}
The present work aims to evaluate the metallurgical and mechanical behavior of dissimilar weld formed by 309L-Si and ERNiCrMo-3 (Inconel 625) electrodes combination on the ASTM A182 F22 steel with GMAW process. The welded joints were characterized by SEM, OM, tensile test and Vickers microhardness technique. The dissimilar interface formed in buttery of 309L and INC625 showed partially mixed zone (PMZ) formation and solidification microcracks that affected the mechanical properties in welded joint, presenting a fragile behavior. The F22 and INC625 interface presented high hardness regions with peaks greater than $400 \mathrm{HV}$. These regions were enriched by carbon due to the diffusion from F22 steel into the weld metal caused by tension relief heat treatment (TRHT).
\end{abstract}

Keywords: Macrosegregation, Decarburization, Solidification microcracks.

\section{Introduction}

Alternative welding techniques and procedures have been explored recently by different chemical segments and power generation and petrochemical industries for dissimilar welding deposition. The great advantage of dissimilar weld techniques are in a more favorable mechanical and corrosion resistance on noble alloys used as a filler metal, to increase the service life and resulting in a low cost production ${ }^{1-3}$. In this context stands out the high strength low alloy steel (HSLA) welding with stainless steel and nickel-based electrodes. The oil and gas industry uses dissimilar welds for structural components coating, bevel buttery or member joining.

For underwater environment applications like valves and manifolds subjected to high mechanical demands is common to use ASTM A182 F22 steel and Cr-Mo HSLA steel $^{4-7}$. These materials must offer a good relationship between mechanical strength and toughness, as specified by NACE MR $0175^{\circ}$.

Due to a high temperability of Cr-Mo steels, their welding joint with an API X80 steel pipe, for example, could form fragile zones. To minimize this problem, the standard procedure use two steps associated with a stress relieving heat treatment ${ }^{4-6,9}$ (SRHT). In the first welding step, an F22 steel member is buttered with a nickel-based alloy, ERNiCrMo-3 (Inconel 625) for example. Subsequently, this member is subjected to a SRHT for tempering the martensite and/or bainite formed in the interface to control the hardness in the heat affected zone (HAZ) to a maximum allowable value of 22 HRC (248 HV) set by the NACE MR0175 standard. After SRHT, the buttery member is machined and then the

*e-mail:dgarcia@ufpa.br union to the lower tempered pipe (X80, for example) can be performed. It should be noted that HAZ is fully seated in the bevel as shown in Figure 1.

Among nickel alloys used as filler metals, Inconel 625 stands out as one of the most commonly used in the F22 steel components buttery, as well as in these union with X80 steel piping in underwater applications. However, the scientific literature needs more information about the best joint configuration, although the excellent mechanical and corrosion resistance, and the lowest thermal expansion coefficient $^{10-15}$. For low temperature application (OFFSHORE), these characteristics could be also provided by an austenitic stainless steel, considering the high cost of nickel-based alloys thus burdening all pipeline assembly operation.

Nickel alloys are usually used as a filler metals because they have a thermal expansion coefficient between HSLA steel and austenitic stainless steel. These alloys also help to delay the carbon diffusion from the ferritic base metal to the weld metal when compare with stainless steel ${ }^{5,16-18}$.

Due to this thermal expansion behavior, Ni-based wires are preferred in dissimilar joint weld. It is common to use this sort of wires in stainless steel welding, to minimize the solidification crack possibility. However, different authors ${ }^{19-22}$ has reported hot cracks in stainless steel weld with Ni-based wires. For $\mathrm{Lin}^{22}$, hot cracking is related to changes in stainless steel constituents, as well as to environmental factors (high temperature, high pressure and high voltage) and operational parameters in the welding procedure (current, voltage, travel speed and wire feed speed).

As all dissimilar weld, there are interfaces with chemical composition gradients between the weld metal and base 


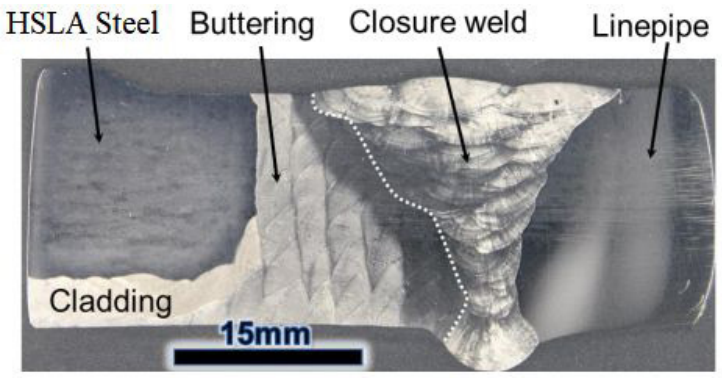

Figure 1. Cross-section macrograph of 8630 - Inconel 625 dissimilar joint ${ }^{5}$.

metal. The melted zone edge is known as partially mixed zone $(\mathrm{PMZ})^{2-7}$.

These components are usually manufactured by traditional welding processes, such as shielding metal arc welding (SMAW), gas tungsten arc welding (GTAW) and gas metal arc welding (GMAW).

Therefore, this study aims to evaluate the effectiveness of 309L-Si depositing on ASTM A182 F22 steel with Inconel 625 buttering layer, based in the metallurgical and mechanical behavior, allowing cost reduction on the welded joint.

\section{Materials and Methods}

Experimental welding was automated and performed in the flat position by GMAW spray transfer mode with ER309L-Si and ERNiCrMo-3 wires, in ASTM A182 F22 steels joints, measuring $200 \times 100 \times 25 \mathrm{~mm}$, and API X80 measuring $200 \times 100 \times 20 \mathrm{~mm}$. Figure 2 is a schematic of $45^{\circ} 1 / 2 \mathrm{~V}$ joint beveled in $45^{\circ}$ in X80 steel, and with $10 \mathrm{~mm}$ buttery in the non-beveled F22 steel.

The Inconel 625 wire was used because it is the standard filler metal in offshore applications. The 309L-Si wire connected to $\mathrm{Cr}-\mathrm{Ni}$, with low carbon content, being indicated for dissimilar weld, presenting excellent weldability and resistance to corrosion, similar to Inconel 625 .

The F22 steel was normalized first at $900{ }^{\circ} \mathrm{C}$ for $1 \mathrm{~h}$ and the buttering deposition was subjected to SRHT at $675^{\circ} \mathrm{C}$ for $1 \mathrm{~h}$. Table 1 shows the chemical composition of base and filler metals.

Buttery welding was performed with preheating between $250-300^{\circ} \mathrm{C}$ as recommended by ASTM A $182^{23}$. A preheating was applied by an electric resistance, held by a thermal blanket and monitored by an infrared digital thermometer to control the F22 steel carbon equivalent $(\mathrm{Ceq}=0.8)$.

Two welded joints were made designated for J625 and J309. In J625 joint a nickel wire (Inconel 625) was used for five buttery layers deposition and filling the bevel. In J309 joint a nickel wire was used for the first two layers deposition and a stainless steel wire (309L-Si) for the three layers remaining, and for filling the bevel. The mixed J309 joint configuration aimed to reduce carbon migration towards the weld metal ${ }^{5,18}$ and the production costs.

Table 2 presents the buttery weld and joint filling parameters. Voltage and current were monitored by an acquisition system at $5 \mathrm{kHz}$ per channel, 13 bits resolution and $\pm 10 \mathrm{~V}$ measurement range. The thermal input was calculated using Equations 1 and 2, recommended by different authors ${ }^{24,25}$.



Figure $2 . \mathrm{V} 45^{\circ}$ half bevel joint and $10 \mathrm{~mm}$ buttery sketch.

Table 1. Base (F22) and filler metals (NiCrMo-3 and 309L-Si) chemical composition. Manufacturer data.

\begin{tabular}{llllll}
\hline \multicolumn{1}{c}{ Material } & $\mathrm{C}$ & $\mathrm{Mn}$ & $\mathrm{Cr}$ & $\mathrm{Ni}$ & $\mathrm{Mo}$ \\
\hline F22 Steel & 0.9 & 0.4 & 2.12 & 0.16 & 0.97 \\
\hline NiCrMo-3 Wire & 0.1 & 0.5 & 21.5 & 58.0 & 9.0 \\
\hline 309L-Si Wire & 0.03 & 1.8 & 23.5 & 13.5 & 0.4 \\
\hline
\end{tabular}

Table 2. Buttery and joint filling parameters.

\begin{tabular}{lcc}
\hline \multicolumn{1}{c}{ Parameters } & Inconel 625 & 309L-Si \\
\hline Shielding gas & $\mathrm{Ar}$ & $\mathrm{Ar}-2 \% \mathrm{O}_{2}$ \\
\hline CTWD $(\mathrm{mm})$ & 15 & 15 \\
\hline Welding Speed $(\mathrm{mm} / \mathrm{s})$ & 5 & 5 \\
\hline Mean voltage $(\mathrm{V})$ & 24.7 & 25.2 \\
\hline Mean current $(\mathrm{A})$ & 215.5 & 241.2 \\
\hline Heat input $(\mathrm{J} / \mathrm{mm})$ & 851.0 & 972.5 \\
\hline
\end{tabular}

$P=\frac{\sum_{i=1}^{n} U_{i} x I_{i}}{n}$

$H=\left(\frac{P}{v}\right) \eta$

Where,

$\mathrm{H}$ is the heat input $(\mathrm{J} / \mathrm{mm})$;

$\mathrm{P}$ is potency $(\mathrm{W})$

$\mathrm{U}$ is the applied voltage (V);

$\mathrm{I}$ is the electric current (A);

$\mathrm{v}$ is the welding speed $(\mathrm{mm} / \mathrm{s})$;

$\eta$ is the welding process thermal efficiency $(0.8$ - usual for GMAW).

After buttery welding, a visual test in the dissimilar interface was performed to inspect for the presence of defects and solidification cracks.

The macrostructure, microstructure and chemical composition analyzes of J615 and J309 welded joints were performed at the F22 steel buttery and HAZ interface with optical, scanning electron microscopy and EDS aid.

The cross section samples were polished with 1.0 and $0.5 \mu \mathrm{m}$ alumina, and chemically etched. The structure of the F22 steel was revealed by immersion chemical attack with Nital $10 \%$ and Nital 2\% (for micrographs). The ERNiCrMo-3 (INC625) and 309L-Si welds microstructure were revealed by $10 \%$ chromic acid and $10 \%$ oxalic acid electrolytic attack, respectively.

The tensile test was based on ASTM- E8 and performed with a strain rate of $0.5 \mathrm{~mm} / \mathrm{min}$ at room temperature at a strain rate of $0.5 \mathrm{~mm} / \mathrm{min}$. at $300 \mathrm{kN}$ SHIMADZU AG-X 
machine. The Vickers hardness test was performed applying a $100 \mathrm{~g}$ load (HV 0.1) for $15 \mathrm{~s}$ and with $200 \mu \mathrm{m}$ indent spacing to profile the buttery and the HAZ of the welded joint.

\section{Results and Discussion}

Figure 3 presents macro and microstructure aspects of J625 welded joint cross section. Figure $3 \mathrm{a}$ indicate absence of lack of fusion, porosities or cracks, which also occurred for J309 welded joint. Figure 3b presents the F22/INC625 interface that shows macrosegregation on the weld metal side and a dark carbon rich region characteristic of the migration of this element to the weld metal direction, which caused a correspondent decarburization on the F22 steel HAZ. Figure $3 \mathrm{c}$ shows a martensitic microstructure on the F22/INC625 weld metal interface related to the microhardness increase on this region. Figure $3 \mathrm{~d}$ indicates microhardness peaks of 240 to $400 \mathrm{HV}$ range.

For Dodge ${ }^{5}$, nickel content reduction on the PMZ results in a weaker driving force for austenite stabilization on lower temperatures during cooling, which when associated to the high defunded carbon content from the base metal, propitiate conditions for martensite formation, even on slower cooling condition. However, due to the higher nickel concentration on the PMZ of the welds deposited with nickel alloys electrodes in comparison with stainless steel electrodes, austenite stabilizes on a larger area inside the PMZ, thus only a thin martensite layer is expected on welds deposited with these alloys.

A chemical profile of the PMZ on the F22/INC625 interface was obtained with aid of EDS chemical analysis. Figure 4 shows this profile from the base metal, highlighting $\mathrm{Fe}, \mathrm{Cr}$ and Ni. From the HAZ to PMZ/planar region there is a gradual increase on $\mathrm{Ni}$ and $\mathrm{Cr}$ content and a reduction of Fe content.

Different authors ${ }^{5,26}$, using Thermo-Calc software, found above $60 \%$ dilution values on planar zone of the F22/INC625 welded joint interface.

Figure 5a presents the austenitic microstructure of Inconel 625 weld metal, with a columnar dendritic solidification structure, which occurs due to the high nickel content, above $50 \%$. On Figure $5 \mathrm{~b}$, in addition to the austenitic microstructure, there are $\mathrm{Mo}$ and $\mathrm{Nb}$ rich interdendritic precipitates. The $\mathrm{Nb}$ segregation to interdendritic regions contributes to eutectic phases formation and for incidence of solidification $\mathrm{cracks}^{26}$.

Figure 6 shows the microstructure of the J309 weld metal. Figure 6a shows the microstructure of the stainless steel, 309L-Si, with austenite predominance on the solidification structure and delta ferrite among dendritic arms.

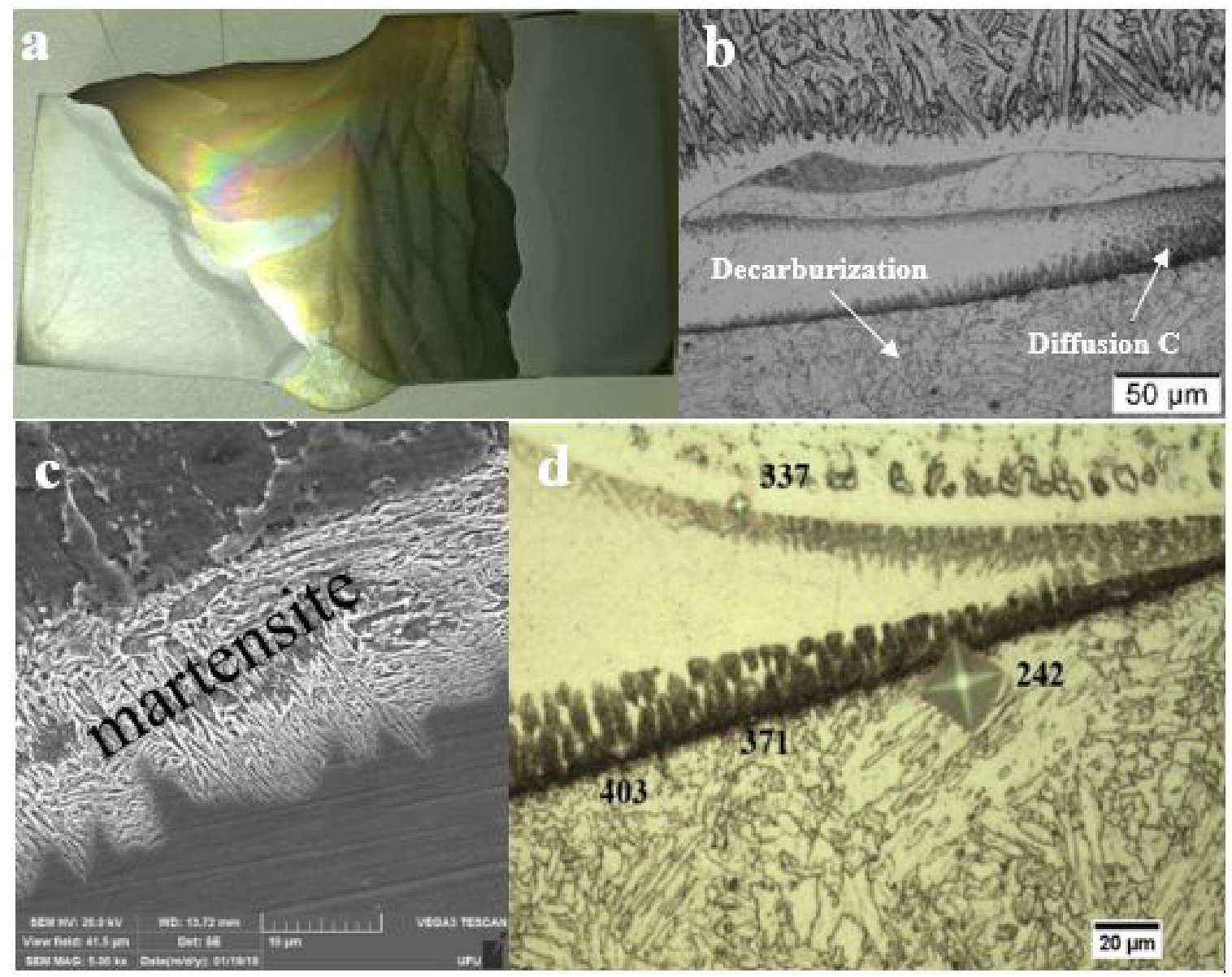

Figure 3. J625 welded joint, a) cross section macrograph, b) F22/INC625 interface, c) martensitic structure on PMZ, d) martensitic region microhardness. 


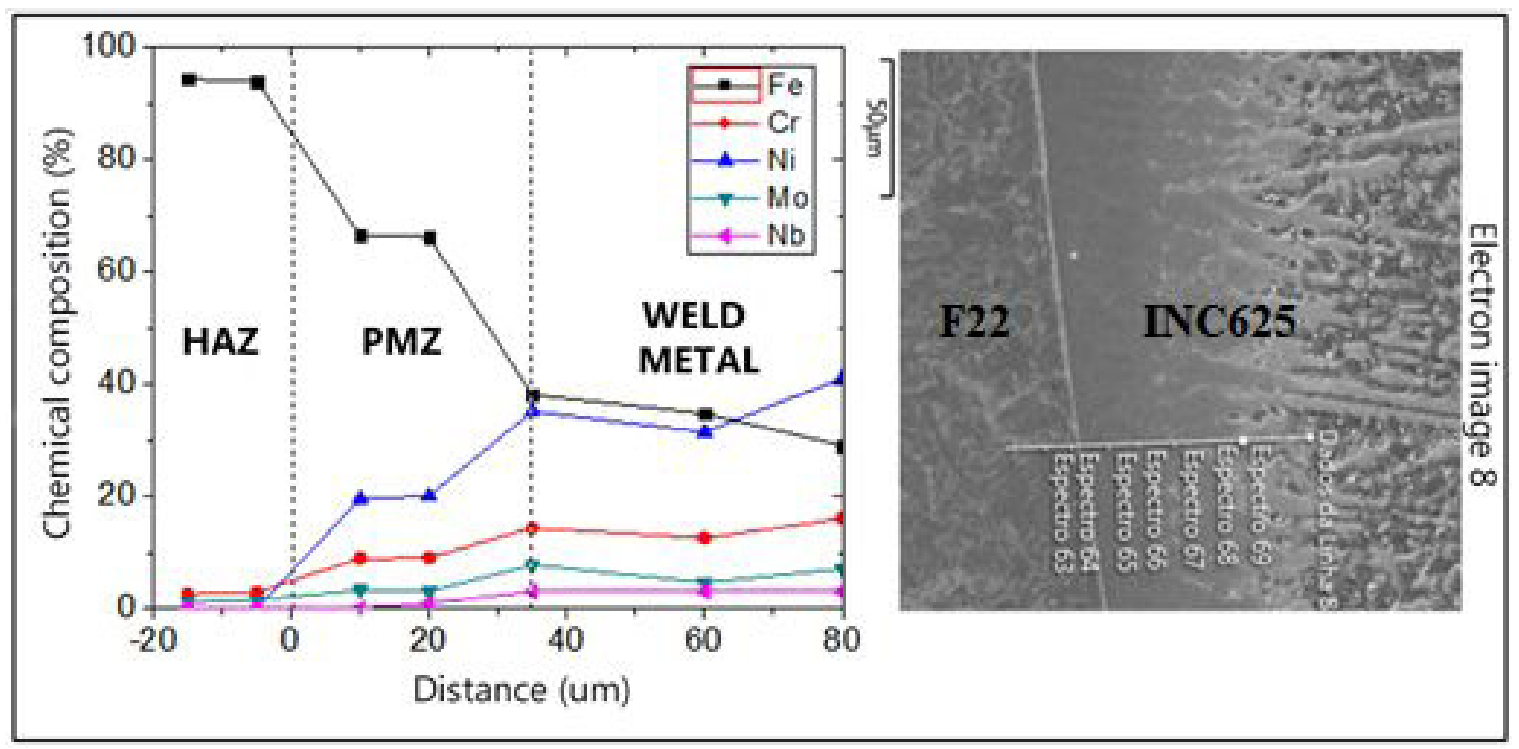

Figure 4. Chemical profile through F22/INC625 interface.


Figure 5. J625 welded joint, a) austenitic microstructure with columnar dendritic growth, b) presence of precipitates among dendritic arms.
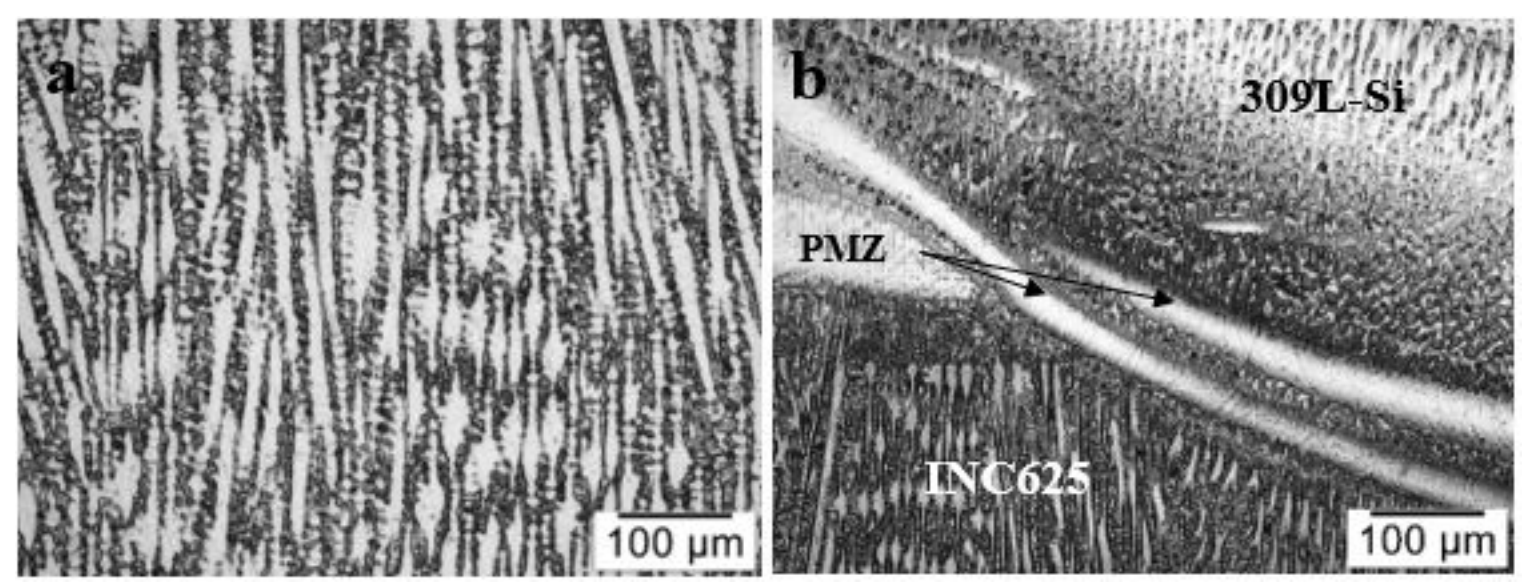

Figure 6. Microstructural aspects of the weld metal of the 309L-Si/INC625 welded joint: a) Dendritic on 309L-Si weld metal, b) PMZ on 309L-Si/INC625 interface. 
With absence of segregated elements such as $\mathrm{Nb}$ and $\mathrm{Mo}$, the main constituents of the stainless steel weld are $\mathrm{Fe}, \mathrm{Cr}$ and Ni. These elements has very low tendency of segregating to interdendritic regions. Figure $6 \mathrm{~b}$ shows the microstructure on the dissimilar 309L/INC625 weld interface, of the J309 welded joint. In this case, the PMZ formation occurs due to insufficient time for coalescence and homogenization of the different fused weld metals, because of high viscosity and cooling rate on the interface.

Figure 7 show the Schaeffler diagram with the composition of the welds on the 309/INC625 interface and on the 309L-Si filling. The presence of a PMZ and the analysis of the Schaeffler diagram (Figure 7) confirmed that the composition of the weld on the 309/INC625 interface of the J309 joint are located on the austenitic region of the diagram. This result corroborates the $\mathrm{PMZ}$ occurrence on the interface.

Figure 8 shows the microhardness profile on 309/INC625 interface with values below $250 \mathrm{HV}$. This result is due to austenitic phase predominance, since the filling weld (Inconel 625 ) presented over $40 \%$ in nickel weight, Figure 9 . It is known from scientific literature ${ }^{26-28}$ that nickel alloys and stainless steel do not suffer solid state transformations during cooling. According to the exposed on Figure 6b, the deposit microstructure on 309L/INC625 interface evidences the PMZ incidence, which occurs in a random way through the interface, not exerting significant effects over microhardness profile, as shown in Figure 9.

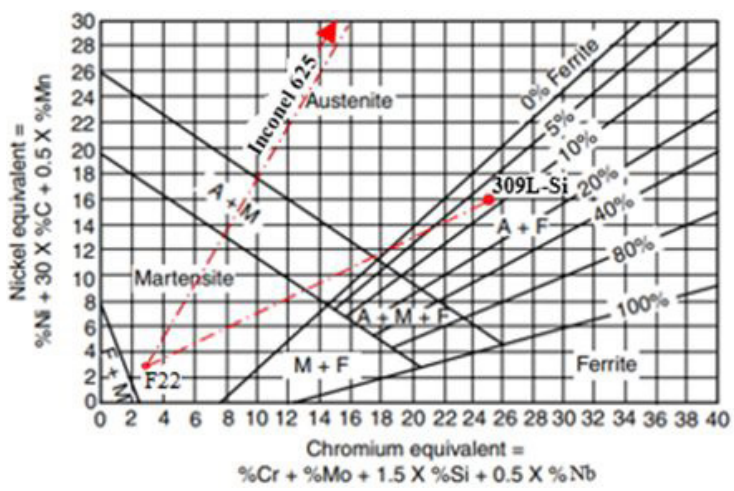

Figure 7. Schaeffler Diagram, alloy composition on 309L/INC625 interface and of 309L alloy on bevel filling.

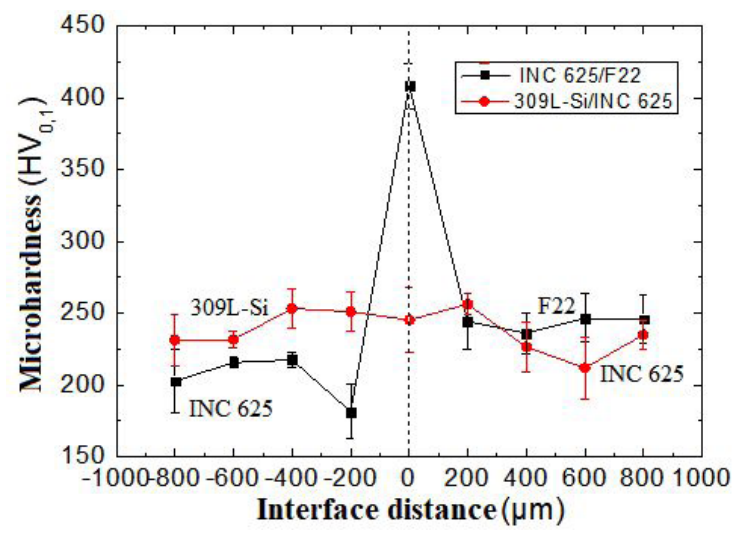

Figure 8. Microhardness profile, J309 welded joint, on 309/INC625 and INC625/F22 interfaces.
On the F22/INC625 interface, Figure 8, the high microhardness is caused by the elevation on carbon content, which migrates from the base metal, F22, to the interface during welding process and SRHT, resulting on martensite formation, Figure 3c.

The EDS analysis on the 309L/INC625 interface are presented on Figure 9. The spectrum 53 is located beside de 309L-Si weld metal, the spectrum 51 is located on the PMZ (interface) and the spectrum 48 is located on the INC 625 weld metal. The chemical composition reported by the spectrum 51 indicate that on the transition of weld metals 309L/INC625, there was a significant variation on chemical composition when comparing to spectrum 48 (309L-Si) and 53 (INC 625), mainly on $\mathrm{Ni}(27,6 \%$ in weight) and $\mathrm{Fe}(31,5 \%$ in weight) values. This chemical composition variation can lead to PMZs formation.

Table 3 presents the tensile test results for J625 and J309 welded joints, in addition to the F22 steel mechanical properties according to ASTM A $182^{23}$. The analysis of the results from this Table indicate that the resistance of the J625

Table 3. Mechanical resistance of the J625 and J309 welded joints, and of the F22 steel according to ASTM A182 F22 23 .

\begin{tabular}{cccc}
\hline Condition & $\sigma_{\mathrm{e}}(\mathrm{MPa})$ & $\sigma_{\mathrm{r}}(\mathrm{MPa})$ & $\varepsilon(\%)$ \\
\hline $\mathrm{F} 22$ & $442.5 \pm 2$ & $577 \pm 7$ & $30 \pm 2$ \\
\hline $\mathrm{J} 625$ & $445.0 \pm 5$ & $591 \pm 8$ & $31 \pm 2$ \\
\hline $\mathrm{J} 309$ & $335.0 \pm 5$ & $504 \pm 2$ & $25 \pm 3$ \\
\hline
\end{tabular}

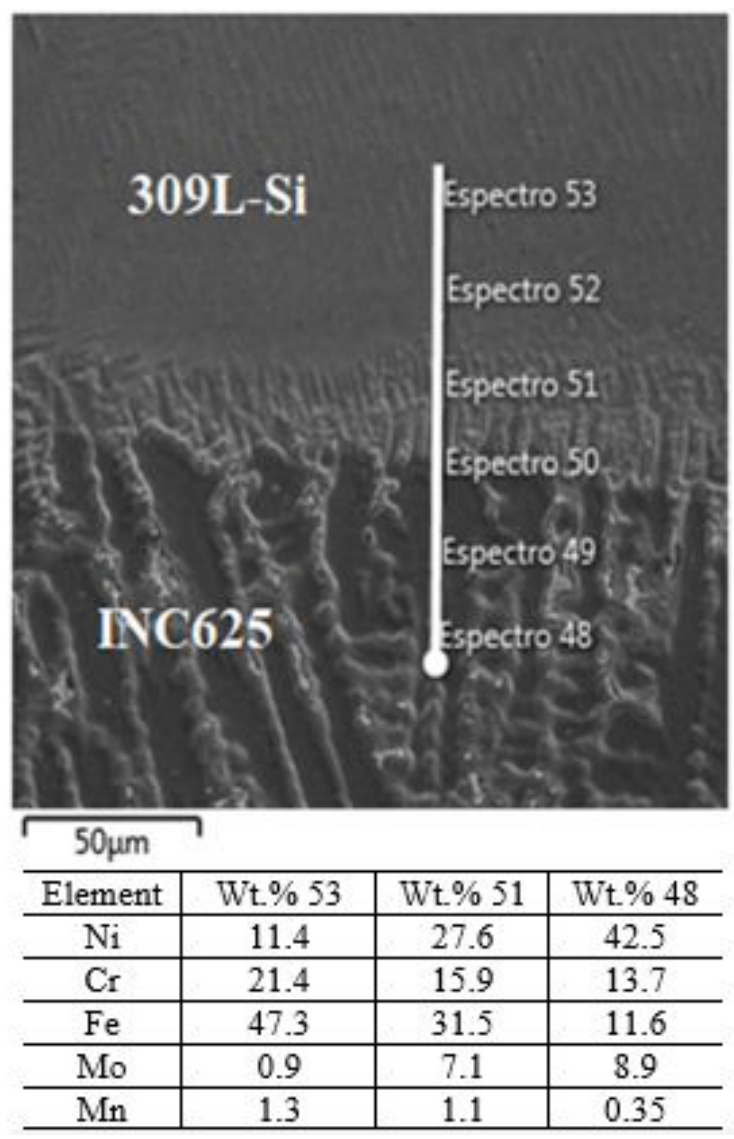

Figure 9. EDS analysis on 309L-Si/INC625 joint. 
joint was equivalent to the F22 steel. Similar resistance and hardness $(220 \mathrm{HV})$ results were obtained by Fassina et al. ${ }^{29}$ and Fallahmohammadi et al..$^{30}$. During this test, the rupture occurred on the base metal of the F22 steel and outside the HAZ, Figure 10a, characterizing the J625 mechanical resistance as equivalent to the F22 steel. The rupture location on the base metal suggests that the decarburization did not affect the resistance of the J625 joint and is the cause of the resistance elevation due to the martensitic structure on the PMZ composition, dislocating the flaws to other regions submitted to preferential plastic deformations.

By Table 3, it is observed that the tensile strength of the J309 welded joint was lower in comparison to J625 joint and to the F22 steel, being the yield strength values, $335 \mathrm{MPa}$, and the tensile strength, $504 \mathrm{MPa}$, which are lower than the recommended by ASTM A182 standard $^{23}$.

Figure 11a shows that a rupture occurred in the 309L-Si buttery zone of J309 joint. Figures $11 \mathrm{~b}$ and $11 \mathrm{c}$ shows the fracture surface in the 309L-Si welded cross section. The failure surface reveals a rapid fracture, probably came from solidification micro-cracks, propagated during the tensile test in 309/INC625 interface. The micrographic exams before the test could not detect these micro discontinuities throughout the interface due to their small dimensions and the internal location, similar to founded by other researchers ${ }^{31-33}$.
By Figure 12 it is possible to note that the solidification cracks on the buttery were restrict to the 309L-Si weld metal, and were possibly caused by two main factors. The first factor was the five layer deposition of the buttery, where the solidification cracks occurred on the 309L-Si layer deposited over a nickel (Inconel 625) layer, causing an increase on the nickel content on the INC625/309L interface and the growth of the austenitic structure, which has low resistance to hot cracks propagation $^{34}$. Besides, the delta ferrite reduction on the 309L-Si weld, Figure 7, was a consequence of the rise of the nickel content on mixed zone of the deposited metal. According to the literature ${ }^{19-21,34,35}$ the austenitic weld metal must have 1 to $8 \%$ delta ferrite fraction in order to avoid impurities segregation such as $\mathrm{S}$ and $\mathrm{P}$ to the interdendritic regions, which may form low melting point phases, which promotes solidification cracking. The second factor, which may have contributed to the solidification cracking, was the residual stress due to the number of the weld layers deposited, in addition to the pre-heating temperature, which may have associated with the formation of low melting point constituents. The cracking susceptibility is also increased due to the higher thermal expansion coefficient of the 309L-Si steel in comparison to the nickel alloy, which creates great stress due to thermal shrinkage and favors hot cracking.

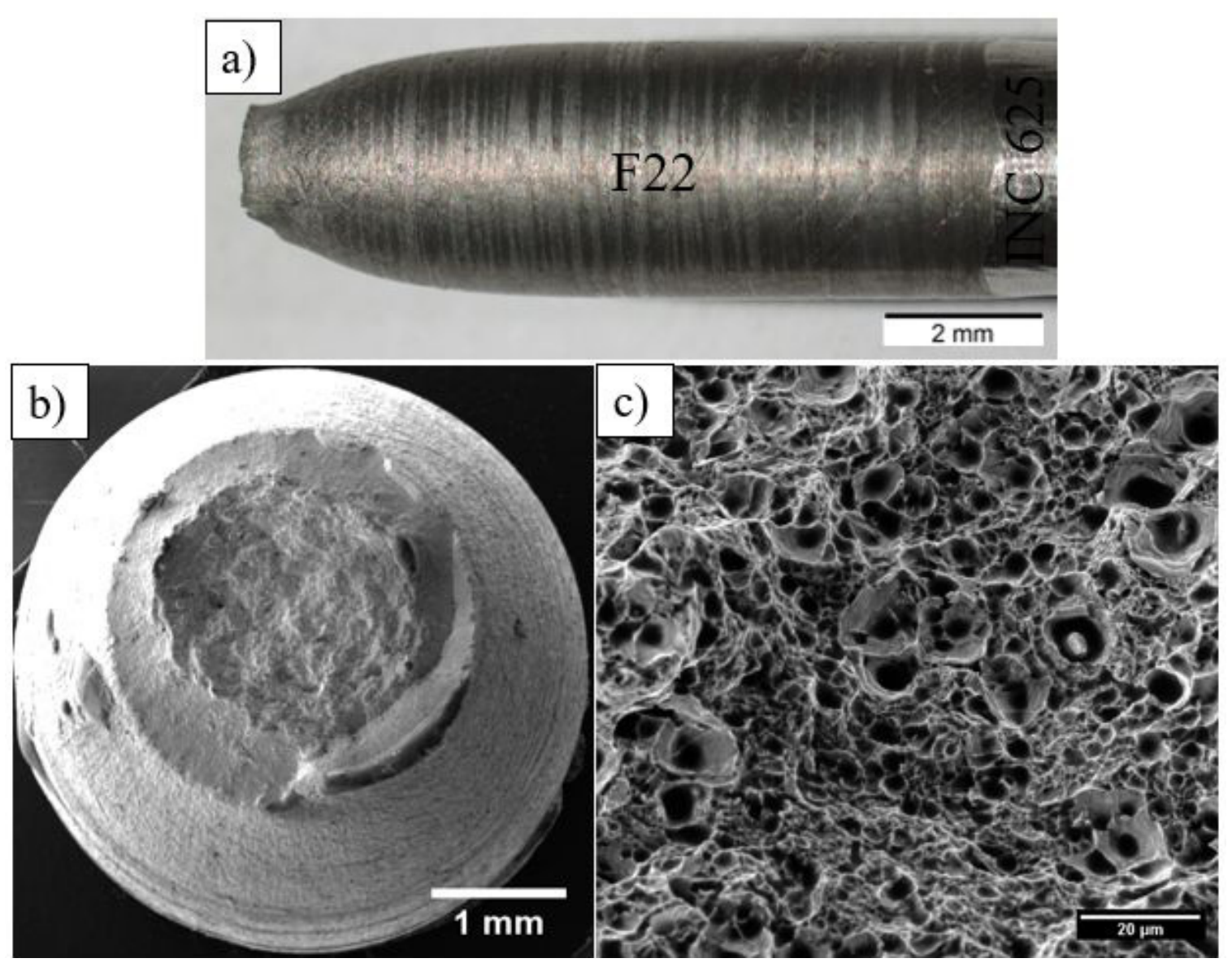

Figure 10. Tensile test aspects, J625 welded joint, a) necking aspect on the fracture section of the F22 steel, b) surface aspect on the F22 fracture cross section (cone), c) microcavities on the F22 fracture surface. 


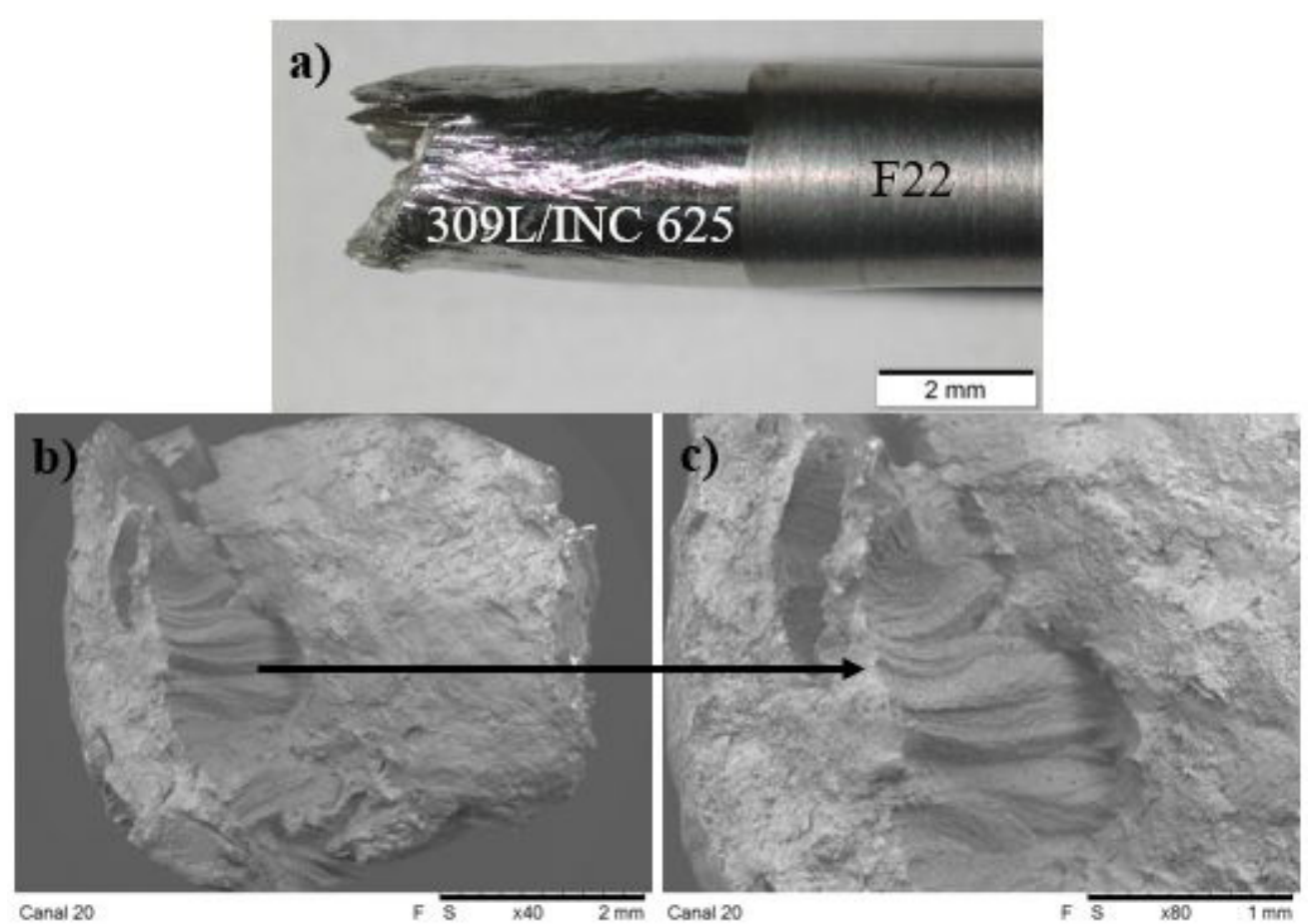

Figure 11. Tensile tests aspects, J309 welded joint, a) absence of necking on the 309L-Si weld fracture section, b) surface aspect on the 309L-Si weld brittle cross section, c) crack on the brittle fracture surface.

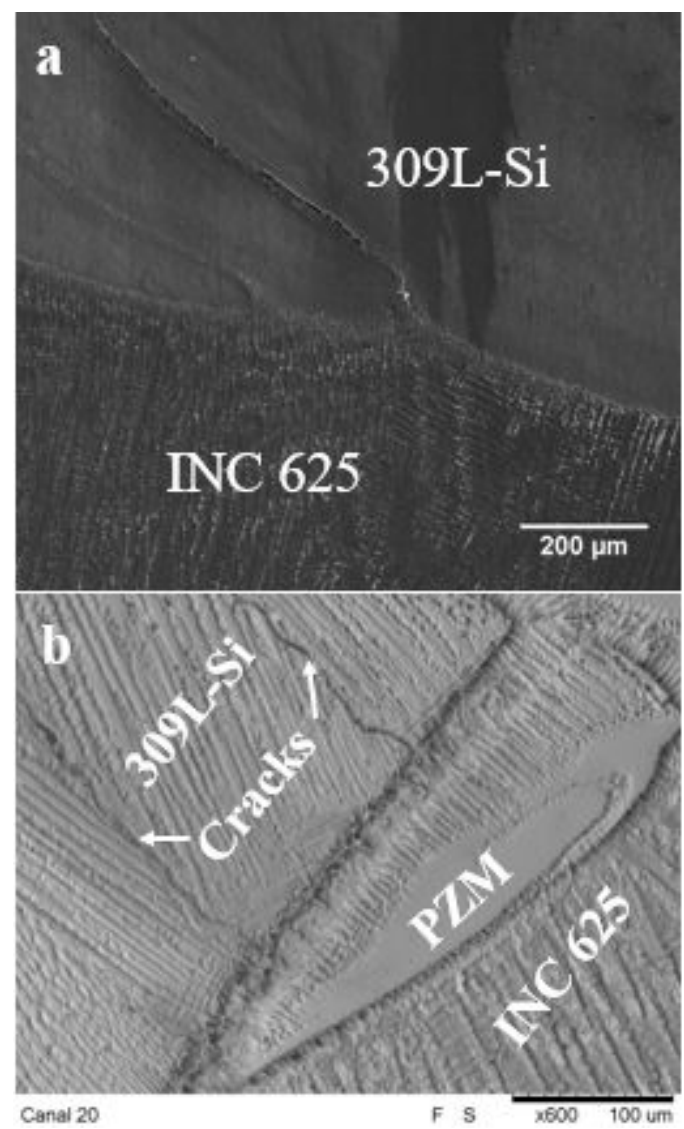

Figure 12. Solidification crack, a) on the 309L-Si weld metal, b) propagated crack starting on the PMZ.

\section{Conclusions}

Based on the experimental results, it is possible to reach the following conclusions:

The dissimilar interface between Inconel 625 and 309L-Si weld metals, and between Inconel 625 weld metal and F22 base metal, resulted on PMZ formation, as a consequence of the intermediate chemical composition between the filler and base metal, and due to the weld pool agitation. These macrosegragations formed randomly (non-continuous) throughout the dissimilar interface.

The nickel alloy ERNiCrMo-3 was the most adequate for buttering in this welding joint. The ER309L-Si in combination with the ERNiCrMo-3 may cause solidification cracking, due to the dilution and to the delta ferrite content.

The SRHT performed during the buttering welds was sufficient to temper and reduce the hardness of the F22 HAZ, but did not guarantee hardness levels below $250 \mathrm{HV}$ on the dissimilar interface (INC625/F22), since carbon migrated from the base metal to the planar zone of the nickel-based weld metal, creating martensitic regions with over $400 \mathrm{HV}$ hardness levels.

The SRHT of the dissimilar welded joints also led to decarburization and grain growth on the F22 HAZ, although it has not affected the mechanical properties of the welded joint.

The J625 welded joint was defect free and it mechanical properties were superior in comparison to the F22 steel.

\section{Acknowledgments}

The authors would like to thank the Center for Research and Development of Welding Processes (LAPROSOLDA) of Federal University of Uberlandia, Brazil, and the 
Welding Technology Study Group (GETSOLDA) of Federal University of Pará, Brazil, for the laboratorial infrastructure and technical support.

\section{References}

1. Fratari RQ, Schvartzman MMA, Scotti A. Weaving parameter optimization for buttering on carbon steel plates by TIG process with an AWS ER309L wire. Soldag Insp. 2010;15(3):209-17.

2. Da Mota CAM, Nascimento AS, Garcia DN, Silva DAS, Teixeira FR, Ferraresi VA. Coating welds with a nickel super alloy deposited by GMAW and GMAW cold wire. Soldag Insp. 2017;21:483-96.

3. Garcia DN. Comportamentos mecânico e metalúrgico de junta soldada em aço ASTM A182 F22 aplicado na indústria offshore [thesis]. Uberlândia: Universidade Federal de Uberlândia; 2018.

4. Garcia DN, Ferraresi VA, Mota CAM. Evaluation of doublelayer weld deposition technique on ASTM A182 F22 steel without postweld heat treatment. J Braz Soc Mech Sci Eng. 2019;41:31325.

5. Dodge MF. The effect of heat treatment on the embrittlement of dissimilar welded joints [thesis]. Leiceste: University of Leicester; 2014.

6. Dodge MF, Dong HB, Milititski M, Barnett RP, Gittos MF. Environment-induced cracking in weld joints in subsea oil and gas systems -part II. In: 32nd International Conference on Ocean, Offshore and Arctic Engineering; 2013; Nantes, France. Proceedings. New York: ASME; 2013.

7. Fenske JA. Microstructure and hydrogen induced failure mechanisms in iron nickel weldments [thesis]. Urbana: University of Illinois; 2010.

8. ISO: International Organization for Standardization. NACE MR0175. Petroleum, petrochemical and natural gas industriesmaterials selection and corrosion control for oil and gas production systems. Geneva: ISO; 2001.

9. Olden V, Kvaale PE, Simense PA, Aaldstedt S, Solberg JK. The effect of PWHT on the materials properties and microstructure in Inconel 625 and Inconel 725 buttered joints. In 22nd International Conference on Offshore Mechanics \& Arctic Engineering; 2003; Proceedings. Cancun, Mexico: OMAE; 2003.

10. Alexandrov BT, Lippold JC, Sowards JW, Hope AT, Saltzmann DR. Fusion boundary microstructure evolution associated with embrittlement of Ni-base alloy overlays applied to carbon steel. Weld World. 2012;57(1):39-53.

11. King JF, Sullivan MD, Slaughter GM. Development of an improved stainless steel to ferritic steel transition joint. Weld J. 1977;2:354-8.

12. Lundin CD. Dissimilar metal welds - transition joints literature review. Weld J. 1982;2:58-63.

13. Gittos MF, Gooch TG. The interface below stainless steel and nickel-alloy claddings. Weld J. 1992;71:461-72.

14. Tsay LW, Lin WL, Cheng SW, Leu GS. Hydrogen sulphide stress corrosion cracking of 2.25Cr-Mo steel weldments. Corros Sci. 1997;39(7):1165-76.

15. Davis JR. Corrosion of dissimilar metal weldments. OH: ASM International; 2006.

16. Gittos MF, Gooch TG. The interface below stainless steel and nickel-alloy claddings. Weld J. 1992;461s-72s.

17. Dupont JN, Banovic SW, Marder AR. Microstructural evolution and weldability of dissimilar welds between a super austenitic stainless steel and nickel-based alloys. Weld J. 2003;82(6):125-56.
18. Dupont JN, Kusko CS. Technical note: martensite formation in austenitic/ferritic dissimilar alloy welds. Weld J. 2007;51-4.

19. Hosseini HS, Shamanian M, Kermanpur A. Characterization of microstructures and mechanical properties of inconel 617/310 stainless steel dissimilar welds. Mater Charact. 2011;(62):42531.

20. Mithilesh P, Varun D, Reddy ARG, Ramkumar KD, Arivazhagan $\mathrm{N}$, Narayanan S. Investigations on Dissimilar Weldments of Inconel 625 and AISI 304. Procedia Eng. 2014;(75):66-70.

21. Hosseini HS, Shamanian M, Kermanpur A. Microstructural and weldability analysis of inconel617/aisi 310 stainless steel dissimilar welds. Int J Press Vessels Piping. 2016;(144):18-24.

22. Lin CM. Relationships between microstructures and properties of buffer layer with Inconel 52M clad on AISI 316L stainless steel by GTAW processing. Surf Coat Tech. 2013;(234):234-41.

23. ASTM: American Society for Testing and Materials. ASTM A182: Standard specification for forged or rolled alloy and stainless steel pipe flanges, forged fittings, and valves and parts for high-temperature service. West Conshohocken: ASTM International; 2005.

24. Dutra JC, Silva RHG, Marques C. Características de fusão e potência de soldagem com a transferência MIG - CMT versus MIG convencional para Alumínio 5183. Soldag Insp. 2013;18(1):12-8.

25. Scotti A, Ponomarev V. Soldagem MIG/MAG: melhor entendimento, melhor desempenho. São Paulo: Artliber, 2008.

26. Silva CC. Nickel alloys weld overlays deposited by TIG welding process with cold wire feeding operational and metallurgical aspects [thesis]. Fortaleza: Universidade Federal do Ceará; 2010.

27. Brooks JA, Thompson AW, Williams JC. A fundamental study of the beneficial effects of delta ferrite in reducing weld cracking. Weld J. 1984;71-83.

28. Brooks JA, Thompson AW. Microstrutural development and solidification cracking susceptibility of austenitic stainless steels welds. Int Mater Rev. 1991;16-44.

29. Fassina P, Bolzoni F, Fumagalli G, Lazzari L, Vergani L, Sciuccati A. Influence of hydrogen and low temperature on mechanical behaviour of two pipeline steels. Eng Fract Mech. 2012;81:43-55.

30. Fallahmohammadi E, Bolzoni F, Fumagalli G, Benassi G, Lazzari L. Hydrogen diffusion into three metallurgical microstructures of a C-Mn X65 and low alloy F22 sour service steel pipelines. Int J Hydrogen Energy. 2014;39:13300-13.

31. Dokme F, Kulekci MK, Esme U. Microstructural and mechanical characterization of dissimilar metal welding of inconel 625 and AISI 316L. Metals (Basel). 2018;8:797-815.

32. Oliveira MJC, Melo RHF, Maciel TM, Araújo CJ. Nickel-titanium alloys welding of thin sheets using GTAW: comparative study between similar and dissimilar welding with AISI 304 stainless steel. Mater Res. 2019;22(1): e20180434.

33. Karahan T, Mert T, Tumer M, Kerimak ZM. Microstructural analysis of inconel 625 nickel alloy/UNS S31803 duplex stainless-steel dissimilar weldments. Advanced Technologies \& Materials. 2019;44(1).

34. Hajiannia I, Shamanian M, Kasiri M. Microstructure and mechanical properties of AISI 347 stainless steel/A335 low alloy steel dissimilar joint produced by gas tungsten arc welding. Materials and Desing. 2013;50:566-573.

35. Easterling K. Introduction to the physical metallurgy of welding. 2. ed. Oxford: Butterworths Heinemann; 1992. 